\title{
Soft tissue expansion: principles and inferred intraoral hydrogel tissue expanders
}

\author{
Henri J.J. Uijlenbroek ${ }^{1,2 *}$, Yuelian Liu ${ }^{1}$ and Daniel Wismeijer ${ }^{1}$ \\ ${ }^{1}$ Department of Oral Implantology and Prosthetic Dentistry, Academic Centre of Dentistry Amsterdam (ACTA), University of Amsterdam and VU University \\ Amsterdam, The Netherlands \\ ${ }^{2}$ Private Practice, Edisonweg 3, 8501 XG Joure, The Netherlands
}

\begin{abstract}
Background: Tension-free closure of the intraoral site is a prerequisite at bone augmentation procedures. Dental surgeons mainly use a technique called soft tissue mobilisation. The soft tissue expander has not yet been used in the daily practice. However, in plastic surgery, soft tissue expansion is often used to create a surplus of soft tissue. The experience gathered in plastic surgery can be extrapolated into intraoral surgery. Especially the new small-sized hydrogel soft tissue expanders can be used intraorally in implant dentistry.

Purpose: This paper presents systematically the principles of soft tissue augmentation. Its purpose is to summarize the general knowledge about soft tissue expanding and the characteristics of tissue expanders. Experience gathered in plastic surgery is transformed to intraoral use. It outlines the advances of tissue expansion and its possible role using hydrogel soft tissue expanders in dental implant therapy.

Materials and methods: The electronic data bases Science Direct, PubMed, High Wire and Google Scholar were searched for articles published until March 2015. The related terms were used.

Result and discussion: Intraoral tissue expansion seems useful and practicable, although complication rates are still high, which could be caused by poor clinical experience. A decision tool is given to decide whether intraoral soft tissue expansion is a treatment option. Although the studies for intraoral use are minimal, the technique is absolutely valid.
\end{abstract}

\section{Introduction}

Soft tissue expansion is a natural phenomenon seen in pregnancy, obesity, tumour growth and (ancient) tribal rituals. In reconstructive plastic surgery tissue expansion has become a common surgical procedure to grow extra skin through controlled mechanical overstretch. It creates skin that matches the colour, texture, and thickness of the surrounding tissue, while minimizing scars and risk of rejection [1]. The goal of tissue expansion is to develop donor tissue by tissue expansion adjacent to [2,3] or in the centre [4] of the site of reconstructive surgery.

In 1957 Neumann [5] introduced a rubber balloon to expand soft tissue in order to reconstruct an ear. In 1984 Radovan [2] placed an expander adjacent to the defect and doubled the size of the donor flap by intermittent injections of normal saline into the expander. The tissue expanders used had an external port to fill them. In 1982 Austad et al. [6] described a self-inflating tissue expander. He used a permeable silicone balloon filled with a saturated $\mathrm{NaCl}$ solution. The disadvantages were the long inflation period of 8 to 14 weeks and the risk of rupture, which could result in necrosis of the overlying tissue. Wiese et al. [79] researched the use of hydrogels for tissue expansion to overcome these problems. This led to the Osmed ${ }^{\oplus}$ hydrogel expander. Hydrogels can imbibe water or biological fluids and thus increase in volume. The smaller-sized Osmed ${ }^{\star}$ hydrogel expanders can be used intraorally.

Hydrogel based soft tissue expanders are used in plastic surgery with moderate $[10,11]$ to good [12-15] results as well as in ophthalmology
$[9,16]$. The use of intraoral soft tissue expanders was first described in 2007 [17] as small hydrogel expanders became available. Animal studies $[18,19]$ as well as human studies [20] have been done.

In this paper we present the history of tissue expansion, the surgery needed in soft tissue expansion procedures and is related problems. The intraoral applications are discussed with their limitations and an indication is provided for the future application in implant dentistry.

\section{Methods}

The electronic data bases Science Direct, PubMed, High Wire and Google Scholar -excluding patents and quotations- were searched for articles published until March 2015. The terms "expander", "oral expander", "dental expander", "dental soft tissue expanders", "oral soft tissue expanders", "intra(-)oral soft tissue expansion", "Osmed expanders" and "Osmed soft tissue expanders" were used. Every article concerning intro-oral soft tissue expansion with Osmed $^{\circledR}$ hydrogel expanders was included. To understand and illustrate soft tissue expansion in plastic surgery basic articles were consulted.

Correspondence to: Henri J.J. Uijlenbroek, Academic Centre of Dentistry Amsterdam (ACTA), Department of Oral Implantology and Prosthetic Dentistry, Gustav Mahlerlaan 3004, 1081 LA Amsterdam, The Netherlands, Tel: +31 513 411988, Fax: +31 513 411972; E-mail: h.uijlenbroek@tandartsjoure.nl

Received: November 10, 2015; Accepted: December 04, 2015; Published: December 06, 2015 


\section{Tissue expanders}

\section{Tissue expansion as a treatment option}

Reconstructive surgical procedures are used to restore or improve defective, damaged or missing structures. In case of a lack of tissue of the same texture and colour, donor tissue can be generated by the healthy tissue next to the reconstruction site by expanding this tissue before the reconstructive surgery takes place [21-23]. Because of their plasticity mucosa and skin can easily adapt to environmental changes [24] and are therefore tissues eminently suitable for being expanded. In intraoral implant surgery there is not always sufficient bone present to place an implant, so a bone augmentation procedure is called for. But for predictable bone regeneration primary wound closure is a prerequisite [25]. If exposure of the augmented material is expected to occur, a surplus of soft tissue may be created before augmentation. A (created) surplus of soft tissue will make tension-free closure of the augmented site easier, or possible at all. Tissue expansion should therefore be considered in the treatment planning in all those cases where a lack of soft tissue of the appropriate quality and / or quantity is to be expected.

\section{Characteristics of an ideal expander}

An expander should have maximum effectiveness without any damage to the tissues and with maximum comfort for patient and surgeon. The ideal characteristics are listed in Table 1. Any material which damages the biological system or its surrounding tissue will cause undesired reactions. Leung et al. [26] reported breast pathology in complications associated with polyacrylamide hydrogel (PAAG) mammoplasty. Less damage to the tissues is created by gradual and slow expansion. It will give the overlying tissues time to expand. Rapid expansion can lead to perforation of the expander [11]. However, a short expansion time reduces treatment time and discomfort for the patient. Less tissue damage will occur at insertion using an expander with a small volume. Besides, a small-sized expander is easier to insert. After insertion and placement of the expander the expander volume will be increased to expand the overlying tissues. The more the expander increases in volume, the more tissue it will expand and generate. For this reason the ratio: volume after expansion/volume before expansion of the expander has to be as large as possible. Any expansion of a tissue expander creates a force. This force is exerted on overlying as well as underlying tissue. The tissue with the least resistance will move the most. If the underlying tissue is hard, such as bone, and the tissue to be expanded is stiff and difficult to expand, such as palatal mucosa, the expander may be dislocated by its own forces when it is not fixated. Therefore a possibility of fixation is a prerequisite. Damage to the surrounding tissues of the expander also depends on the shape of the expander. Peak pressure during expansion is caused by an angular part of the expander rather than by a rounded shape. So the tissue expander should have rounded shapes. Damage to the underlying tissue depends on the local peak pressure to which it is exposed. A large adaptable surface will distribute the pressure on the underlying tissues more evenly, so that excessive pressure at one point will decrease. Even in the best of circumstances tissue expansion, may damage the underlying tissue, and for instance result in bone resorption $[27,28]$. The surgical procedure will be unnecessarily complicated when the tissue expander or its filling port is difficult to find. Camilleri et al. [29] reported 7\% failure in locating the filling port with the Becker tissue expander in reconstructive surgery of the breast after mastectomy. To overcome the use of ultrasound to find the filling port is described [30].

\section{Advantages of soft tissue expansion}

Obtaining tissue to restore defects can be done in several ways. In maxillofacial reconstructive surgery after ablative surgery, vascularized osseous free flaps still represent the gold standard of restoration [31]. However, the donor site loses some quality. To obtain donor tissue, tissue engineering can also be used. The tissues are produced in vitro, which makes it possible to have sufficient tissue. However, incorporating engineered tissue in the host is not always easy, because of the absence of a vascular network [32]. Tissue expansion on the other hand can create tissue of the same colour, texture, hair-bearing characteristics and thickness adjacent to the restoration site [33]. It minimizes scars and risk of rejection. Tissue expansion is a less radical approach compared to vascularized osseous free flaps and at the moment less complicated than tissue engineering. Once enough donor soft tissue has been gained adjacent to the restoration site, it can easily be harvested locally maintaining blood supply. Angiogenesis is a prerequisite for good wound healing [25]. A fortunate consequence of tissue expansion is a significant increase in vascularity $[27,34]$.

\section{Types of expanders}

Several types of expander exist, varying in material, size, filling substitute, filling port and filling valve. Shapes may vary: round, rectangular, tubular or crescent-shaped. The expanded sizes vary from about $0.35 \mathrm{ml}$ (cupola Dental Osmed ${ }^{\circledR} \mathrm{GmbH}$ ) to $1300 \mathrm{ml}$ (Integra ${ }^{\circ}$ breast expanders).

Most expanders consist mainly of a silicone balloon with an injection port. The silicone balloon is gradually filled with saline so that the expander increases in volume. In 1976 Radovan [2] designed the first silicone expander inflated by means of a sealed remote-injection port placed under the skin. The technique has been widely utilised. The expander is inflated regularly over a period of several weeks. Depending on the expander type and size patients have to visit their surgeon sometimes several times a week. This may be inconvenient

Table 1. Characteristics of an ideal tissue expander.

\begin{tabular}{|l|}
\hline Made of an inert material \\
\hline Gradual and slow expanding process. \\
\hline Expanding process as short as possible. \\
\hline $\begin{array}{l}\text { The ratio: volume after expansion/volume before expansion of the expander has to be as } \\
\text { large as possible. }\end{array}$ \\
\hline An option of fixation. \\
\hline A rounded shape of the expander. \\
\hline $\begin{array}{l}\text { The surface area of the side of the tissue expander adjacent to the underlying tissue should } \\
\text { be: as large as possible and adaptable to form and size of the underlying tissue. }\end{array}$ \\
\hline $\begin{array}{l}\text { The expander - and its filling port, if applicable - should easily be recognisable in the } \\
\text { operation field during placement and removal. }\end{array}$ \\
\hline
\end{tabular}

No toxic damage to the surrounding tissues

Less discomfort for the patient.

Less likely to perforate because the tissue has time to adapt.

Reduction of treatment time.

A maximum of tissue generated.

Keeping the expander in place during expansion

Reduction of the risk of perforation during expansion.

The pressure to the underlying structures will be better distributed so local peak pressure is minimized.

Comfort and effectiveness for the surgeon.

operation field during placement and removal. 
to the patient and surgeon. Home inflation of a tissue expander has been developed [35] but is not widely spread. As the filling port of the silicone balloon expander can be localised on the expander, the latter may be damaged by the needle when it is being filled, because it is sometimes difficult to palpate the port. Percentages of inability to find the filling port vary between $2.8 \%$ [36] and $4 \%$ [37]. The filling port may also be connected to the expander by a tube, so that it can be placed at a distance from the expander and the expanding tissue, which reduces the risk of damaging the expander at filling. Very rarely however, the tube can be impenetrable to the saline, when it is twisted, for instance. Most tissue expanders have a subcutaneous self-sealing injection port placed through a separate incision in a pocket dissected at the time of expander placement. It can be fixed with sutures to prevent movement and to make it easier to find. Sometimes this type of filling port is hard to find.

The latest generation of expanders consists of hydrogels. In contrast to the balloon expander they are self-inflating and therefore have no filling port. Hydrogels are cross-linked polymers that have hydrophilic groups and can therefore absorb fluids. The material's properties range from hard and tough to soft and weak, depending on the amount of inhibited fluids. Biomedical and pharmaceutical hydrogel applications include a wide range of systems and processes that utilize several molecular design characteristics [38]. In a review Drury et al. [39] classified hydrogel applications for tissue engineering in three categories: space filling, bioactive molecule delivery and cell/ tissue delivery. Space filling hydrogels used as tissue expanders were developed in 1993 [7]. The Osmed ${ }^{\circledR}$ hydrogel tissue expander (Figure 1 ) is based on an osmotically active hydrogel. The self-filling device is

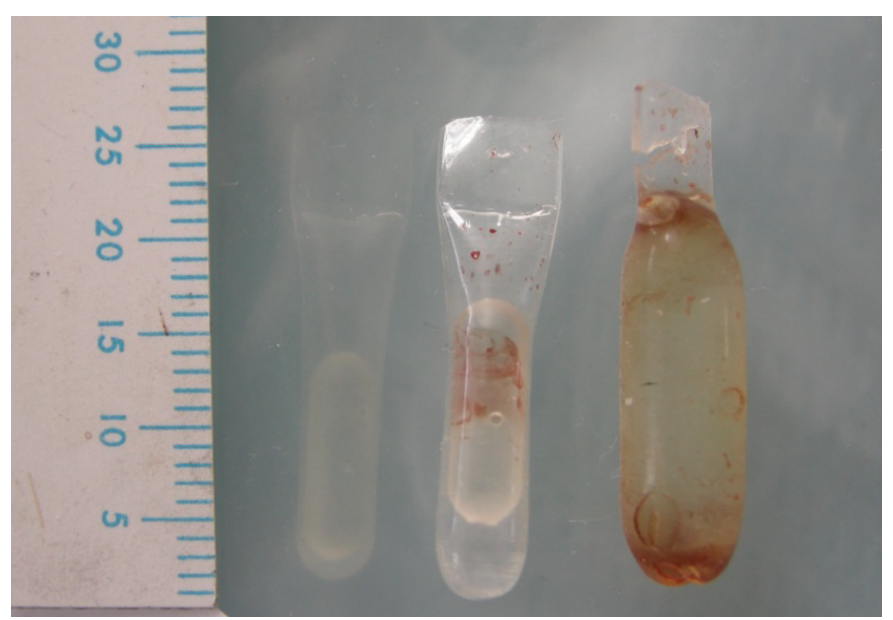

Figure 1. Osmed ${ }^{\circledR}$ Tissue Expander - Cylinder $0.7 \mathrm{ml}$ : sizes before and after $1 \mathrm{~h}$ and 43 days swelling.

Table 2. Comparison of silicone balloon expander and hydrogel expander. made of a cross-linked hydrogel consisting of co-polymers based on methyl-methacrylate (MMA) and N-vinylpyrrolidone. Preoperatively Osmed $^{\circledast}$ hydrogel tissue expanders in their pre-expanded state are hard and easy to handle. After implantation Osmed ${ }^{\circledR}$ hydrogel implants start to absorb body fluid and grow consistently to a predefined form and size. The volume of the expander - dependent on the product type increases between 3 to 12 times and thus leads to an increase of soft tissue. Some of the Osmed ${ }^{\star}$ expanders are enveloped in a perforated silicone shell. Through the holes in the shell the body fluids are absorbed, thus inducing volume increase. A non-enveloped hydrogel expander will have faster expansion compared to a hydrogel tissue expander in a silicone envelope and is therefore more likely to lead to mucosa necrosis [40]. The perforated shell reduces the swelling speed and almost linear growth is achieved. The expansion of enveloped Osmed $^{\star}$ hydrogel expanders is regular and predetermined by their osmotic properties and the permeability of their silicone envelopes, which both are predetermined by the manufacturer. The regular visits to the surgeon for inflation are no longer necessary.

Both the silicone expanders and the hydrogel expanders have their advantages and disadvantages, which are summarized in Table 2.

\section{Disadvantages of soft tissue expanders}

Just as in any treatment the use of tissue expanders has also a flip side. The treatment time for patients and clinicians is increased as the expander has to be placed in an additional procedure. After expansion and maturation of the expanded tissue the expander has to be removed. This can be carried out at the same time as the reconstructive surgical procedure, so explanation will be no extra burden. If an expander is used which needs to be filled on a regular basis, the patient has to visit the surgery several times. It is not very time-consuming, but can be an extra load to the patient and surgeon. At filling, fluid is injected into the expander and the increased tension on the skin can cause some discomfort. Discomfort and pain both depend on the location of the expander and on the adaptability and compliance of the patient. The expander has to be in place for a certain time, which can be from several weeks to several months, depending on the expander used and the location of the expander. The skin over the expander frequently appears bluish or pink. This discoloration is caused by the revascularization process and fades after final reconstruction. Tissue expanders involve extra costs, which makes the procedure more expensive. On the other hand, using a soft tissue graft or engineered soft tissue also involves costs. As stated before, tissue expansion may affect its underlying structure. However, there is no concord in the literature on the behaviour of the tissues beneath the tissue expander after the expansion has been completed. Some researchers $[18,27,28]$ reported bone resorption beneath the tissue expander, but others did not [41], and others again claimed bone gain [42].

Silicone Balloon Expander

Hydrogel Expander

Soft, easy to adapt to the underlying tissues.

Soft, not always easy to get unfolded in its pocket.

Hard, not adaptable to the underlying tissues.

Hard, easy to push into its pocket.

Possibility of delayed expansion after placement of the expander.

Filling port.

Regular filling moments needed for expansion.

Immediate expansion, starts as soon as body fluids touch the hydrogel.

No filling port.

Expansion speed can be handled at the filling moments.

No filling moments.

Expansion speed cannot be influenced by the surgeon.

Expansion peaks.

End volume can be handled by the filling.

Leakage of the expander can damage the surroundings tissues.

More gradual expansion provided it is enveloped.

End volume pre-defined.

Leakage of the expander impossible. 


\section{Complications related to soft tissue expanders}

Exposure of the tissue expander is a common clinical complication, reported in about $11.1 \%$ of the cases [36]. Fast expansion will not allow the overlying tissue to stretch, but may cause penetration by the expander [11,43]. Expander exposure has been attributed to several factors: too rapid expansion, dehiscence of the incision, a fold in the expander that eroded through the skin, inadequate tissue coverage or manipulation of the expander by a noncompliant patient [43]. Infection of the expander pocket, the expander or the filling port is possible $[36,37,43,44]$. Therefore aseptic techniques are to be followed during surgery and during inflation in the office. Hematoma should not be underestimated because it can lead to infection [37]. It has been reported that the filling port cannot be found when a tissue expander with an external filling port is used [29]. The disadvantage of the hydrogel expander if used without silicone envelope is its uncontrolled rapid swelling, which may lead to perforation [11]. To overcome this problem Anwander et al. [40] introduced a silicone envelope with some holes in it in which the hydrogel is sealed. The expanding process of a hydrogel expander stays uncontrolled. The hydrogel expander cannot be deflated. Varying with the area in which hydrogel expanders were extra-orally, 0-25\% complications have been reported [45].

\section{Clinical applications and surgical procedure}

Since the early 1980s tissue expansion has been used in a wide field of surgery: burns, head and neck surgery, the reconstructive treatment of face and scalp defects, breast surgery, congenital nevi, congenital anophthalmos, trauma and intraoral bone augmentation. $[13,16,33,36,43,46,47]$. In well selected cases in which there is a lack of donor tissue the technique of tissue expansion can provide donor tissue with minimal donor area morbidity. Depending on the location of the tissue expansion the patient should be willing to undergo several surgeries and accept some discomfort for several weeks with sometimes extreme deformity, which however, seldom results in an unusual appearance. Smoking $[29,48]$ and previous radiotherapy [29] are relative contraindications. Several factors affecting tissue expansion treatment planning will be discussed below.

\section{Location of the tissue expander}

Some authors recommend placing the tissue expander adjacent to the site which has to be reconstructed $[3,13]$. In breast reconstruction surgery [13], as well as in the treatment of congenital anophthalmos [9], the expander is placed in the centre. Lin Fang et al. [4] placed the tissue expanders under the centre of the lesions which had to be removed and fully expanded the surrounding normal tissue. It was named the "expansion in situ" technique. The method chosen depends on each individual case. If a rectangular tissue expander is used it is important to look at Langer's lines. Langer's lines correspond to the natural orientation of collagen fibres in the dermis, and are generally parallel to the orientation of the underlying muscle fibres. There is more tissue growth when the expanders are positioned along the strongest direction of the material to be expanded, and thus aligned with Langer's lines [49].

\section{Amount of donor tissue desired}

The shape, size and insertion location of the tissue expander should make it possible to gain more soft tissue surface than needed in the reconstructive surgery. At insertion, expansion and reconstructive phase attention should be paid to the following two requirements: the vascularization of the (gained) tissue should be kept intact and the soft tissue gained should match the colour, texture and contour of the area to be restored.

\section{Choosing the type, size and shape of the expander}

With a silicone balloon expander the initial filling moment can be postponed to give the incision time to heal. When an extra-oral silicone balloon expander is used, it is recommended [3] to start expansion 7-10 days post insertion of the expander, but only if the skin flaps are in good condition. A hydrogel expander is preferable if the process of expansion can be self-regulated by the hydrogel expander or when very small sizes are needed, unless immediate expansion is a contraindication.

The size of the expander is determined by the amount of soft tissue which has to be gained. If the expander is placed adjacent to the defect, its length should be at least the length of the defect to be covered. The biggest expander possible should be chosen [3] and the number of expanders that can be placed through a minimal number of incisions should be maximized [50].

The shape of the expander depends on the form of the defect and the surface increase of the expander. In 1988 it was suggested, on the basis of a mathematical and a pig model, that the form of an expander should ideally be rectangular, because this gives an increase of surface area of $38 \%$ as opposed to only $25 \%$ for round expanders [51]. Johnson et al. [27] reported that the factual amount of increased skin resulting from immediate intra-operative expansion was unknown but varied between $15 \%$ and $31 \%$. More recent research has been shown that under the same pressure applied to the same surface area, the circular expander induces the largest amount of fractional area gain (1.588), followed by the square (1.368), the rectangular (1.200) and the crescentshaped (1.113) expanders [49,52]. If possible use a circular expander.

We should keep in mind that a volume increase is not the same as a surface increase. Osmed ${ }^{\star}$ claims correctly that with tissue expander Osmed $^{\circ} 400-1070$ cylinder dental $0.7 \mathrm{ml}$ (Figure 1), the volume increases from $0.15 \mathrm{ml}$ to $0.70 \mathrm{ml}$ after swelling, which is 4.66 times. The length (l) $\times$ diameter (d) increases from $12 \times 4 \mathrm{~mm}$ to $20 \times 7 \mathrm{~mm}$. According to the mathematical law - surface of a cylinder $=2 \pi^{1 / 2} \mathrm{~d}$ $(1 / 2 \mathrm{~d}+1)$, the surface increases from $175.93 \mathrm{~mm}^{2}$ to $516.79 \mathrm{~mm}^{2}$, which is only 2.94 times, compared to the 4.66 volume increase. Besides, the surface gain of the overlying soft tissue will be less than the surface gain of the tissue expander, because the tissue expander also gains surface to the opposite side.

\section{The insertion of the expander}

Choose for theinsertion incision a location in the final reconstruction area which minimizes the aesthetic impact of the incision. The shorter the incision, the smaller the scar and the risk of wound dehiscence. The non-desired tissue, such as burn scars or amalgam tattoos can be excised together with the insertion incision at the time of the final reconstruction. The expander can be placed through a flap, tunnel or an endoscopic approach. In plastic surgery a subcutaneous pocket is usually created adjacent to the defect in which the expander is placed [3]. The pocket created to place the expander should be larger than the expander or pressure necrosis will occur. The expander should be completely covered by soft tissue [3]. To minimize patient discomfort the expander is removed at the reconstructive surgery, which takes place about two weeks after the expansion has been completed in which period the tissue has to mature. The expander port through which expander filling is regulated can be placed in a remote location subcutaneously or left outside for easy filling. An endoscopic approach for the placement of tissue expanders showed fewer complications at 
the placement of the expander than the flap, tunnel/pocket dissection method [50,53]. The suture should never be under tension when the insertion incision is being closed. The location of the suture should be sufficiently far away from the expander(s), so that the insertion incision will not open in the expansion phase, as there will be forces on the suture and the tissues it is connecting.

\section{Intraoral applications}

The amount of soft tissue gained by mobilization only is limited. Therefore it is important to find an additional technique in which more soft tissue of good quality can be gained. Steigmann [54] promotes the periosteal pocket flap, which allows easier tension-free soft tissue closure in difficult horizontal bone grafting procedures as well as increase in the stability of the augmentation material. $\mathrm{He}$ states, however, that the periosteal pocket flap is not usable for difficult vertical grafting procedures. Severely atrophic mandibles are hard to augment $[55,56]$. Especially in vertical bone augmentation procedures complications such as membrane exposure occur [55,57-59].

Intraoral tissue expansion prior to bone augmentation is an option. However, intraoral space is limited. Therefore the silicone balloon expander is not used intraorally: not only it is too big but the filling port is also of more discomfort to the patient than in extra-oral use. Recent research into intraoral soft tissue expansion has been limited to Osmed $^{\star}$ hydrogel expanders. Osmed ${ }^{\oplus}$ delivers 2 types of tissue expanders for intraoral use. The Osmed ${ }^{\circledR}$ cylinder dental expander is used in straight edentulous areas, the mandible and maxillary lateral areas. The Osmed ${ }^{\star}$ cupola dental is used in small gaps (1-2 missing teeth) or curved edentulous areas, the maxillary and mandibular frontal area. Osmed ${ }^{\star}$ delivers surgical templates whose dimensions mimic the expanders in non-expanded and expanded state. They are very helpful in deciding the appropriate expander size. With the soft tissue gained it should be possible to make a flap in such a way that the defect which has to be restored can be closed tension-free. Great attention must be given to the uninterrupted blood supply of the flap. Research into intraoral tissue expansion with Osmed $^{\oplus}$ expanders started in 2007 [17], but has resulted in only a few pre-clinical and intraoral clinical studies, summarized below. Table 3 shows the study outcomes of the pre-clinical studies as does Table 4 for the intraoral clinical studies. The cells left empty were no subject of the study.

Table 3. An overview of pre-clinical studies concerning Osmed ${ }^{\circledR}$ hydrogel expanders for intra-oral appliances. The cells left empty were no subject of the study.

\begin{tabular}{|c|c|c|c|c|}
\hline Study & $\mathbf{N}$ & $\begin{array}{c}\text { Soft } \\
\text { Tissue } \\
\text { Gain }\end{array}$ & $\begin{array}{c}\text { Bone } \\
\text { Resorption }\end{array}$ & Micro Circulation In: \\
\hline \multicolumn{5}{|l|}{ Pre-Clinical Studies } \\
\hline Stuehmer et al. [18] & $3 \times 6$ & & yes & \\
\hline von See et al. [28] & $4 \times 7$ & & yes & \\
\hline von See et al. [60] & $6 \times 8$ & & & $\begin{array}{l}\text { periosteum ischemia, } \\
\text { replacement after } 14 \text { days by } \\
\text { connective tissue }\end{array}$ \\
\hline von See et al. [34] & $2 \times 8$ & & & $\begin{array}{l}\text { mucosa increases during entire } \\
\text { treatment period }\end{array}$ \\
\hline Abrahamsson et al. [19] & 8 & yes & no & \\
\hline Abrahamsson et al. [42] & 13 & yes & no & \\
\hline Abrahamsson et al. [61] & 11 & yes & no & \\
\hline Wysocki et al. [62] & $4 \times 14$ & yes & & \\
\hline Uijlenbroek et al. [41] & $4 \times 6$ & yes & no & \\
\hline Kaner et al. [63] & 10 & & & $\begin{array}{l}\text { mucosa shows momentary } \\
\text { disturbance }\end{array}$ \\
\hline Kaner et al. [64] & 10 & & & $\begin{array}{c}\text { mucosa increases if expanded } \\
\text { before augmentation }\end{array}$ \\
\hline \multicolumn{5}{|c|}{$\mathrm{N}=$ number of animals treated with tissue expanders. } \\
\hline
\end{tabular}

Table 4. An overview of intraoral clinical studies using Osmed ${ }^{\circledR}$ hydrogel expanders. The cells left empty were no subject of the study.

\begin{tabular}{|c|c|c|c|c|}
\hline Study & $\mathbf{N}$ & Complications & $\begin{array}{c}\text { Soft } \\
\text { Tissue } \\
\text { Gain }\end{array}$ & Bone \\
\hline \multicolumn{5}{|c|}{ Intraoral Clinical Studies } \\
\hline Kobus [17] & 19 & $36.8 \%$ fistula & yes & \\
\hline Jenq et al. [65] & 7 & $\begin{array}{c}28.6 \% \text { no complete closure } \\
\text { of fistula }\end{array}$ & & \\
\hline von See et al. [20] & 1 & $0 \%$ & yes & \\
\hline Park et al. [66] & 2 & $0 \%$ & yes & A \\
\hline Mertens et al. [67] & 8 & $27.3 \%$ perforated & yes & A \\
\hline Kaner et al. [47] & 12 & $\begin{array}{l}8.5 \% \text { perforated } \\
\text { and } \\
8.5 \% \text { infected }\end{array}$ & yes & \\
\hline Abrahamsson et al. [48] & 10 & $20.0 \%$ perforated & yes & A \\
\hline
\end{tabular}

\section{Pre-clinical studies}

- In Lewis' rat studies placement of Osmed ${ }^{\circledR}$ tissue expanders directly on the bone resulted in bone resorption $[18,28]$. Subperiosteal placement of $\mathrm{Osmed}^{\star}$ tissue expanders led to complete ischemia of the periosteum [60] which within 2 weeks was replaced by connective tissue with increased microvessel density [34].

- In rabbit studies subperiosteal placement of $\mathrm{Osmed}^{\circledR}$ tissue expanders resulted in no signs of any inflammatory reaction and no evidence of bony resorption. New bone had formed at the edges of the expanded periosteum $[19,42,61]$. However, after four weeks tissue healing had not been completed and limited scar formation was visible [62].

- A goat maxilla study using different surgical techniques (a flap and a tunnel approach) [41] did not show any difference in soft tissue volume between the two techniques. No bone resorption beneath the expander was reported.

- A beagle dog study showed only a momentary disturbance of mucosal microcirculation after sub-mucosal implantation of self-filling osmotic tissue expanders [63]. Another study by the same research group showed that when performing a vertical ridge augmentation the microcirculation was better in the sites which had first been expanded and then augmented, than in the sites which had been augmented at once [64].

\section{Intraoral clinical studies}

- In cleft palate repair a preliminary report using Osmed $^{\circledR}$ soft tissue expanders without silicone envelope showed poor quality and quantity of the soft tissue gained and fistula in 36,8 \% [17]. However, when Osmed $^{\star}$ soft tissue expanders with silicone envelope were used no complete closure of secondary palatal fistulas was achieved in $28.6 \%$ [65].

- Two case reports about the use of Osmed $^{\circledR}$ soft tissue expanders prior to bone augmentation showed $100 \%$ success $[20,66]$. However it were only 3 cases. A prospective observational study showed $27.3 \%$ perforations [67]. On the other hand a case series of vertical augmentation procedures showed $8,5 \%$ perforation, but also $8,5 \%$ fistula and $4 \%$ graft exposition occurred [47]. In a prospective study [48] different augmentation procedures were used in the reference-soft tissue expander- and control groups. In the soft tissue expander group occurred 20\% small perforations, but less resorption of the bone grafts in both lateral and vertical dimensions. 
In every study all the expanders expanded. None of the studies which observed soft tissue gain and reported this, however, quantified it. In the pre-clinical studies there is no consensus as to bone resorption takes place or not. The micro-circulation in the mucosa seems to increase, though with a momentary disturbance at the start of the expansion phase. The micro-circulation in the periosteum seems to be completely ischemic, which leads to replacement by connective tissue. In clinical studies with $\mathrm{n}>2$, the complication rate differs from $17.0 \%$ - 36.8\%. The highest complication rate however, is shown in the first study [17] where there was no clinical experience at all and Osmed ${ }^{\oplus}$ expanders were used without silicone envelopes. The expansion time was only 24 - 48 hours. Every other clinical study shows relatively high complication rates. Study designs, measurements methods and results differ, which makes the studies hard to compare and scientifically solid conclusions difficult. More significant research in this field is needed.

\section{General discussion}

Lots of factors influence the success rate of reconstructive surgery, such as: patient selection, surgery planning, scheduling, poor or good communication among staff [68], surgical skills and experience $[69,70]$, materials used and post-operative wound healing as well as infection and host response [71]. Performing intraoral bone augmentation procedures primary closure is a prerequisite [25,56]. This is also endorsed by the negative effect on guided bone regeneration (GBR) at exposure of an expanded polytetrafluoroethylene (ePTFE) membrane or a resorbable membrane during healing [72]. However it has been reported that $5 \%$ (resorbable membranes) to $20 \%$ (non-resorbable membranes) suffer from exposure and/or infection [58] although complete or almost complete coverage of the initial defect was obtained. Besides, the exposed non-expanded polytetrafluoroethylene (nPTFE) membranes covering bone grafts provide tissue which is suitable for implant placement $[73,74]$. A retrospective study [59] using a titanium reinforced ePTFE membrane and particulate autogenously harvested bone in 27 GBR sites shows an overall success of $85.2 \%$. The exposure of the membrane did not affect the dental implant placement in the augmented site negatively.

Exposure of a membrane may not be as jeopardizing as has been suggested. But we still see the need for future research. Splitthickness skin contains all of the epidermis but only part of the dermis, and this frequently leads to scarring. Interestingly, fullthickness skin transplantation is not usually associated with scarring [75]. An animal study showed that functional microvessel density in the expanded region increased, which was associated with more rapid osseointegration of the augmentation material [34]. It would be interesting to see if intraoral soft tissue expansion realized before bone augmentation would lead to better soft tissue quantity and quality, faster osseointegration of the augmentation material and more or less intraoral scar tissue, which is clinically relevant only in the smile line. However, gaining soft tissue before bone augmentation procedures in dental surgery leads to additional costs. It is also an extra burden for the patient owing to the inconvenience in the expansion and maturation phases of the expanded tissue. Every clinical intraoral study using Osmed $^{\star}$ expanders shows relatively high complication ratios (Table 4) although in the majority of cases there is success. The complication ratio may be due to a lack of clinical experience and insufficient refinement of surgery or to the properties of the Osmed ${ }^{\star}$ expander or to a combination of both. Whichever the cause is, the intraoral use of tissue expanders has its limitations. We need to refine surgical intraoral tissue expansion. Sound scientific research is necessary to clarify the balance between making difficult intraoral augmentations possible,

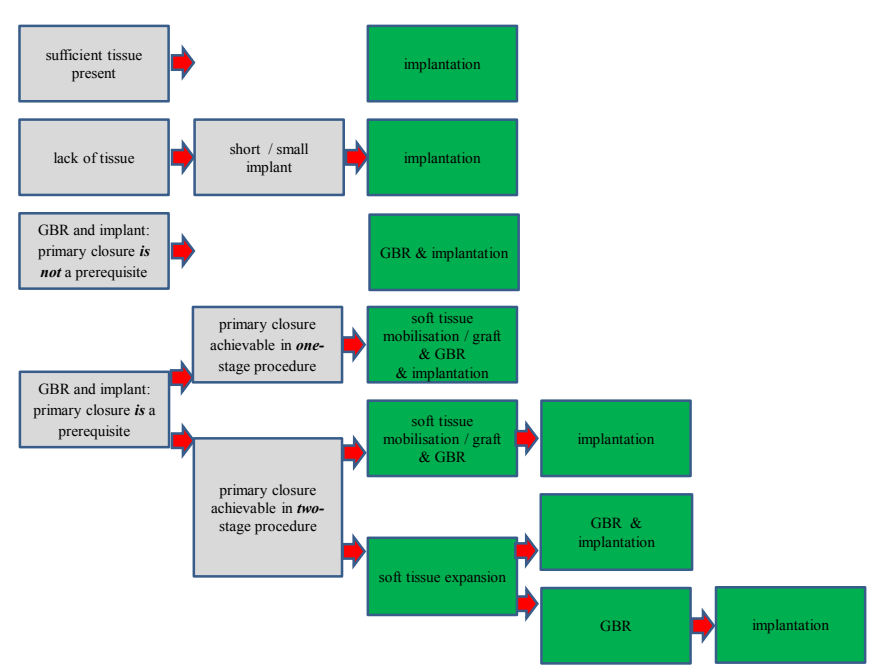

Figure 2. Limitations, conditions and procedures of the soft tissue expanders are indicated in the application of implant dentistry.

easier and more successful on the one hand and stopping the increase of costs, (operation) time and patient discomfort on the other.

The use of intraoral soft tissue expanders may be considered in those cases whereby insufficient bone and soft tissue is present for implant placement. A protocol in which cases intraoral soft tissue expansion may be useful is not yet available. Using a soft tissue expander would mean a two-stage or three-stage procedure. In the first stage the augmentation of soft tissue by placement of the soft tissue expander. The second stage consists of removal of the tissue expander and placement of the bone substitute with or without implant. Finally the dental implant has to be placed if impossible during the third stage. Our decision tree in Figure 2 shows how seldom the use of intraoral soft tissue expanders is indicated. At designing the decision tree we five factors had in mind:

a) Is it absolutely necessary to place a dental implant in a location with a bone deficiency?

b) Is it possible to get support for the supra structure elsewhere?

c) Is a shorter/smaller implant an option?

d) Primary closure is a prerequisite and soft tissue mobilisation only is probably insufficient to cover the graft?

e) Is the patient willing to undergo a three-stage surgery?

\section{Future applications}

Simple, inexpensive, fast and very successful surgery with no discomfort to the patient is the ultimate goal of every surgeon. The more extensive and complex the surgery is, the more 'heroic', the more complications will arise. As early as 2003 it was stated [76] that for easy bone augmentation procedures the clinical handling and / or the biological process should be simplified. For this new materials are needed.

It was concluded [10] that hydrogel expansion devices should be used with caution, because of the unmanageable process of expansion. The Osmed $^{\oplus}$ expander is isotropic: its swelling is identical in every direction. We would prefer swelling in a defined direction. This can reduce (possible) bone resorption and provide for more soft tissue in the desired place. To solve this particular problem Oxford University 
Isis Innovation [77] has developed an intelligent hydrogel material for tissue expansion. It is anisotropic, so the swelling direction can be controlled. It has a maximum swelling ratio of up to 13.6 times, depending on the ratio vinylpyrrolidone/methyl methacrylate. Surgeons will then be able to control accurately and predictably the direction, timing, and rate of the expansion of the material in the body. This will significantly reduce the risk of soft tissue damage and associated complications.

Having the need for new materials in mind we should have a closer look at the hydrogel expanders. There are ordinary hydrogels and the so-called smart hydrogels. The ordinary hydrogels only undergo the swelling de-swelling process, depending on the availability of water in their environment, and do nothing else. The smart hydrogels have additional properties such as drug delivery [78], bio-separation, biosensors and tissue engineering [79]. Safety, biodegradability, drug loading capacity and drug release kinetics are crucial properties in drug delivery systems. Minimally invasive mandibular bone augmentation using injectable hydrogels has been successful with subperiosteal injections of hydrogels as carriers of BMP-2 in rats [80]. It will be challenging to design an ideal device which mimics natural soft tissue expansion; in the meantime, to be a carrier for bone growth factors, such as BMP-2 to induce local bone formation in an ectopic area. However, clinical appliances with smart expanders do not exist as yet.

\section{References}

1. Zöllner AM, Buganza Tepole A, Gosain AK, Kuhl E (2012) Growing skin: tissue expansion in pediatric forehead reconstruction. Biomech Model Mechanobiol 11: 855867. [Crossref]

2. Radovan C (1984) Tissue expansion in soft-tissue reconstruction. Plast Reconstr Surg 74: 482-492. [Crossref]

3. Hudson DA, Grob M (2005) Optimising results with tissue expansion: 10 simple rules for successful tissue expander insertion. Burns 31: 1-4. [Crossref]

4. Fang L, Zhou C, Yang M (2013) 'Expansion in-situ' concept as a new technique for expanding skin and soft tissue. Exp Ther Med 6: 1295-1299. [Crossref]

5. neumann CG (1957) The expansion of an area of skin by progressive distention of a subcutaneous balloon; use of the method for securing skin for subtotal reconstruction of the ear. Plast Reconstr Surg (1946) 19: 124-130. [Crossref]

6. Austad ED, Rose GL (1982) A self-inflating tissue expander. Plast Reconstr Surg 70: 588-594. [Crossref]

7. Wiese KG (1993) Osmotically induced tissue expansion with hydrogels: a new dimension in tissue expansion? A preliminary report. J Craniomaxillofac Surg 21: 309313. [Crossref]

8. Wiese KG, Heinemann DE, Ostermeier D, Peters JH (2001) Biomaterial properties and biocompatibility in cell culture of a novel self-inflating hydrogel tissue expander. $J$ Biomed Mater Res 54: 179-188. [Crossref]

9. Wiese KG, Vogel M, Guthoff R, Gundlach KK (1999) Treatment of congenital anophthalmos with self-inflating polymer expanders: a new method. JCraniomaxillofac Surg 27: 72-76. [Crossref]

10. Obdeijn MC, Nicolai JP, Werker PM (2009) The osmotic tissue expander: a three-year clinical experience. J Plast Reconstr Aesthet Surg 62: 1219-1222. [Crossref]

11. Rees L, Morris P, Hall P (2008) Osmotic tissue expanders in cleft lip and palate surgery: a cautionary tale. J Plast Reconstr Aesthet Surg 61: 119-120. [Crossref]

12. Bergé SJ, Wiese KG, von Lindern JJ, Niederhagen B, Appel T, et al. (2001) Tissue expansion using osmotically active hydrogel systems for direct closure of the donor defect of the radial forearm flap. Plast Reconstr Surg 108: 1-5, discussion 6-7. [Crossref]

13. Ronert MA, Hofheinz H, Manassa E, Asgarouladi H, Olbrisch RR (2004) The beginning of a new era in tissue expansion: self-filling osmotic tissue expander--four-year clinical experience. Plast Reconstr Surg 114: 1025-1031. [Crossref]

14. Chummun S, Addison P, Stewart KJ (2010) The osmotic tissue expander: a 5-year experience. J Plast Reconstr Aesthet Surg 63: 2128-2132. [Crossref]
15. Lohana P, Moiemen NS, Wilson YT (2012) The use of Osmed(TM) tissue expanders in paediatric burns reconstruction. Ann Burns Fire Disasters 25: 38-42. [Crossref]

16. Tse DT, Abdulhafez M, Orozco MA, Tse JD, Azab AO, et al. (2011) Evaluation of an integrated orbital tissue expander in congenital anophthalmos: report of preliminary clinical experience. Am J Ophthalmol 151: 470-482. [Crossref]

17. Kobus KF (2007) Cleft palate repair with the use of osmotic expanders: a preliminary report. J Plast Reconstr Aesthet Surg 60: 414-421. [Crossref]

18. Stuehmer C, Rücker M, Schumann P, Bormann KH, Harder Y, et al. (2009) Osseous alterations at the interface of hydrogel expanders and underlying bone. $J$ Craniomaxillofac Surg 37: 258-262. [Crossref]

19. Abrahamsson P, Isaksson S, Gordh M, Andersson G (2009) Periosteal expansion of rabbit mandible with an osmotic self-inflatable expander. Scand J Plast Reconstr Surg Hand Surg 43: 121-125. [Crossref]

20. von See C, Rücker M, Bormann KH, Gellrich NC (2010) Using a novel self-inflating hydrogel expander for intraoral gingival tissue expansion prior to bone augmentation. Br J Oral Maxillofac Surg 48: e5-6. [Crossref]

21. Sharpe DT, Burd RM (1989) Tissue expansion in perspective. Ann R Coll Surg Engl 71: 175-181. [Crossref]

22. Elshahat A (2011) Management of burn deformities using tissue expanders: a retrospective comparative analysis between tissue expansion in limb and non-limb sites. Burns 37: 490-494. [Crossref]

23. Kheradmand AA, Garajei A, Motamedi MH (2011) Nasal reconstruction: experience using tissue expansion and forehead flap. J Oral Maxillofac Surg 69: 1478-1484. [Crossref]

24. Zöllner AM, Buganza Tepole A, Kuhl E (2012) On the biomechanics and mechanobiology of growing skin. J Theor Biol 297: 166-175. [Crossref]

25. Wang HL, Boyapati L (2006) "PASS" principles for predictable bone regeneration. Implant Dent 15: 8-17. [Crossref]

26. Leung KM, Yeoh GP, Chan KW (2007) Breast pathology in complications associated with polyacrylamide hydrogel (PAAG) mammoplasty. Hong Kong Med J 13: 137-140. [Crossref]

27. Johnson TM, Lowe L, Brown MD, Sullivan MJ, Nelson BR (1993) Histology and physiology of tissue expansion. J Dermatol Surg Oncol 19: 1074-1078. [Crossref]

28. von See C, Rücker M, Schumann P, Goetz F, Wefstaedt P, et al. (2010) Microcomputed tomography and histologic evaluation of the interface of hydrogel expander and underlying bone: influence of pressure distributors on bone resorption. J Oral Maxillofac Surg 68: 2179-2184. [Crossref]

29. Camilleri IG, Malata CM, Stavrianos S, McLean NR (1996) A review of 120 Becker permanent tissue expanders in reconstruction of the breast. Br J Plast Surg 49: 346351. [Crossref]

30. Kohler R, Kritikos N, Poletti PA, Bianchi S (2005) Sonographic detection of a subcutaneous twisted expander injection port. J Ultrasound Med 24: 1441-1444. [Crossref]

31. Kim BC, Kim S, Nam W, Cha IH, Kim HJ (2012) Mandibular reconstruction with vascularized osseous free flaps: a review of the literature. Asian Pac J Cancer Prev 13: 553-538. [Crossref]

32. Kannan RY, Salacinski HJ, Sales K, Butler P, Seifalian AM (2005) The roles of tissue engineering and vascularisation in the development of micro-vascular networks: a review. Biomaterials 26: 1857-1875. [Crossref]

33. Rivera R, LoGiudice J, Gosain AK (2005) Tissue expansion in pediatric patients. Clin Plast Surg 32: 35-44, viii. [Crossref]

34. von See C, Gellrich NC, Jachmann U, Laschke MW, Bormann KH, et al. (2010) Bone augmentation after soft-tissue expansion using hydrogel expanders: effects on microcirculation and osseointegration. Clin Oral Implants Res 21: 842-847. [Crossref]

35. Mohmand MH, Sterne GD, Gowar JP (2001) Home inflation of tissue expanders: a safe and reliable alternative. Br J Plast Surg 54: 610-614. [Crossref]

36. Cunha MS, Nakamoto HA, Herson MR, Faes JC, Gemperli R, et al. (2002) Tissue expander complications in plastic surgery: a 10-year experience. Rev Hosp Clin Fac Med Sao Paulo 57: 93-97. [Crossref]

37. Yanko-Arzi R, Cohen MJ, Braunstein R, Kaliner E, Neuman R, et al. (2009) Breast reconstruction: complication rate and tissue expander type. Aesthetic Plast Surg 33: 489-496. [Crossref] 
38. Peppas NA, Huang Y, Torres-Lugo M, Ward JH, Zhang J (2000) Physicochemical foundations and structural design of hydrogels in medicine and biology. Аnпи Rev Biomed Eng 2: 9-29. [Crossref]

39. Drury JL, Mooney DJ (2003) Hydrogels for tissue engineering: scaffold design variables and applications. Biomaterials 24: 4337-4351. [Crossref]

40. Anwander T, Schneider M, Gloger W, Reich RH, Appel T, et al. (2007) Investigation of the expansion properties of osmotic expanders with and without silicone shell in animals. Plast Reconstr Surg 120: 590-595. [Crossref]

41. Uijlenbroek HJ, Liu Y, He JF, Visscher C, van Waas MA, et al. (2011) Expanding soft tissue with Osmed tissue expanders in the goat maxilla. Clin Oral Implants Res 22: 121-128. [Crossref]

42. Abrahamsson P, Isaksson S, Gordh M, Andersson G (2010) Onlay bone grafting of the mandible after periosteal expansion with an osmotic tissue expander: an experimental study in rabbits. Clin Oral Implants Res 21: 1404-1410. [Crossref]

43. Goodman T, White S, Shenaq SM (1987) Tissue expansion. A new modality in reconstructive surgery. AORN J 46: 198-20, 204-5, 208-9 passim. [Crossref]

44. Elshahat A (2009) Exteriorization of buried port to salvage infected tissue expander. Eplasty 9: e37. [Crossref]

45. Al Madani JO (2014) Second generation self-inflating tissue expanders: a two-year experience. Plast Surg Int 2014: 457205. [Crossref]

46. Donelan MB, Garcia JA (2008) Purse-string closure of scalp defects following tissue expansion: an effective aesthetic alternative. J Plast Reconstr Aesthet Surg 61: 419-422. [Crossref]

47. Kaner D, Friedmann A (2011) Soft tissue expansion with self-filling osmotic tissue expanders before vertical ridge augmentation: a proof of principle study. $J$ Clin Periodontol 38: 95-101. [Crossref]

48. Abrahamsson P, Wälivaara DÅ, Isaksson S, Andersson G (2012) Periosteal expansion before local bone reconstruction using a new technique for measuring soft tissue profile stability: a clinical study. J Oral Maxillofac Surg 70: e521-530. [Crossref]

49. Tepole AB, Gosain AK, Kuhl E (2012) Stretching skin: The physiological limit and beyond. Int J Non Linear Mech 47: 938-949. [Crossref]

50. Egeland BM, Cederna PS (2008) A minimally invasive approach to the placement of tissue expanders. Semin Plast Surg 22: 9-17. [Crossref]

51. van Rappard JH, Molenaar J, van Doorn K, Sonneveld GJ, Borghouts JM (1988) Surface-area increase in tissue expansion. Plast Reconstr Surg 82: 833-839. [Crossref]

52. Tepole AB, Ploch CJ, Wong J, Gosain AK, Kuhl E (2011) Growing skin: A computational model for skin expansion in reconstructive surgery. J Mech Phys Solids 59: 2177-2190. [Crossref]

53. Toranto JD, Yu D, Cederna PS (2007) Endoscopic versus open tissue-expander placement: is less invasive better? Plast Reconstr Surg 119: 894-906. [Crossref]

54. Steigmann M, Salama M, Wang HL (2012) Periosteal pocket flap for horizontal bone regeneration: a case series. Int J Periodontics Restorative Dent 32: 311-320. [Crossref]

55. Esposito M, Grusovin MG, Felice P, Karatzopoulos G, Worthington HV, et al. (2009) The efficacy of horizontal and vertical bone augmentation procedures for dental implants - a Cochrane systematic review. Eur J Oral Implantol 2: 167-184. [Crossref]

56. Pellegrini G, Pagni G, Rasperini G (2013) Surgical Approaches Based on Biological Objectives: GTR versus GBR Techniques. Int J Dent 2013: 521547. [Crossref]

57. Chiapasco M, Romeo E, Casentini P, Rimondini L (2004) Alveolar distraction osteogenesis vs. vertical guided bone regeneration for the correction of vertically deficient edentulous ridges: a 1-3-year prospective study on humans. Clin Oral Implants Res 15: 82-95. [Crossref]

58. Chiapasco M, Zaniboni M (2009) Clinical outcomes of GBR procedures to correct periimplant dehiscences and fenestrations: a systematic review. Clin Oral Implants Res 20 Suppl 4: 113-123. [Crossref]

59. Lindfors LT, Tervonen EA, Sándor GK, Ylikontiola LP (2010) Guided bone regeneration using a titanium-reinforced ePTFE membrane and particulate autogenous bone: the effect of smoking and membrane exposure. Oral Surg Oral Med Oral Pathol Oral Radiol Endod 109: 825-830. [Crossref]

60. von See C, Gellrich NC, Bormann KH, Rahmann A, Rücker M (2010) Microvascular response to the subperiosteal implantation of self-inflating hydrogel expanders. Int J Oral Maxillofac Implants 25: 979-984. [Crossref]

61. Abrahamsson P, Isaksson S, Andersson G (2011) Guided bone generation in a rabbit mandible model after periosteal expansion with an osmotic tissue expander. Clin Oral Implants Res 22: 1282-1288. [Crossref]

62. Wysocki M, Kobus K, Szotek S, Kobielarz M, Kuropka P, et al. (2011) Biomechanical effect of rapid mucoperiosteal palatal tissue expansion with the use of osmotic expanders. J Biomech 44: 1313-1320. [Crossref]

63. Kaner D, Zhao H, Terheyden H, Friedmann A (2014) Submucosal implantation of soft tissue expanders does not affect microcirculation. Clin Oral Implants Res 25: 867-870. [Crossref]

64. Kaner D, Zhao H, Terheyden H, Friedmann A (2015) Improvement of microcirculation and wound healing in vertical ridge augmentation after pre-treatment with self-inflating soft tissue expanders - a randomized study in dogs. Clin Oral Implants Res 26: 720724. [Crossref]

65. Jenq TF, Hilliard SM, Kuang AA (2011) Novel use of osmotic tissue expanders to treat difficult anterior palatal fistulas. Cleft Palate Craniofac J 48: 217-221. [Crossref]

66. Park SH, Choi SK, Jang JH, Kim JW, Kim JY, et al. (2013) Self-inflating oral tissue expander for ridge augmentation in the severely atrophic mandible. $J$ Korean Assoc Oral Maxillofac Surg 39: 31-34. [Crossref]

67. Mertens C, Thiele O, Engel M, Seeberger R, Hoffmann J, et al. (2015) The use of selfinflating soft tissue expanders prior to bone augmentation of atrophied alveolar ridges. Clin Implant Dent Relat Res 17: 44-51. [Crossref]

68. Segall N, Bonifacio AS, Schroeder RA, Barbeito A, Rogers D, et al. (2012) Can we make postoperative patient handovers safer? A systematic review of the literature. Anesth Analg 115: 102-115. [Crossref]

69. de la Rosette JJ, Laguna MP, Rassweiler JJ, Conort P (2008) Training in percutaneous nephrolithotomy--a critical review. Eur Urol 54: 994-1001. [Crossref]

70. Clementini M, Morlupi A, Canullo L, Agrestini C, Barlattani A (2012) Success rate of dental implants inserted in horizontal and vertical guided bone regenerated areas: a systematic review. Int J Oral Maxillofac Surg 41: 847-852. [Crossref]

71. Thomas MV, Puleo DA (2011) Infection, inflammation, and bone regeneration: a paradoxical relationship. J Dent Res 90: 1052-1061. [Crossref]

72. Machtei EE (2001) The effect of membrane exposure on the outcome of regenerative procedures in humans: a meta-analysis. J Periodontol 72: 512-516. [Crossref]

73. Barber HD, Lignelli J, Smith BM, Bartee BK (2007) Using a dense PTFE membrane without primary closure to achieve bone and tissue regeneration. J Oral Maxillofac Surg 65: 748-752. [Crossref]

74. Barboza EP, Stutz B, Ferreira VF, Carvalho W (2010) Guided bone regeneration using nonexpanded polytetrafluoroethylene membranes in preparation for dental implant placements--a report of 420 cases. Implant Dent 19: 2-7. [Crossref]

75. Böttcher-Haberzeth S, Biedermann T, Reichmann E (2010) Tissue engineering of skin. Burns 36: 450-460. [Crossref]

76. Hämmerle CH, Jung RE (2003) Bone augmentation by means of barrier membranes. Periodontol 2000 33: 36-53. [Crossref]

77. Swan MC, Bucknall DG, Goodacre TE, Czernuszka JT (2011) Synthesis and properties of a novel anisotropic self-inflating hydrogel tissue expander. Acta Biomater 7: 11261132. [Crossref]

78. Qiu Y, Park K (2001) Environment-sensitive hydrogels for drug delivery. Adv Drug Deliv Rev 53: 321-339. [Crossref]

79. Lee SC, Kwon IK, Park K (2013) Hydrogels for delivery of bioactive agents: a historical perspective. Adv Drug Deliv Rev 65: 17-20. [Crossref]

80. Martínez-Sanz E, Varghese OP, Kisiel M, Engstrand T, Reich KM, et al. (2012) Minimally invasive mandibular bone augmentation using injectable hydrogels. $J$ Tissue Eng Regen Med 6 Suppl 3: s15-23. [Crossref]

Copyright: (C2015 Uijlenbroek HJJ. This is an open-access article distributed under the terms of the Creative Commons Attribution License, which permits unrestricted use, distribution, and reproduction in any medium, provided the original author and source are credited. 